\title{
'Whistleblowers face blast of hostility'
}

[SEATTLE] Whistleblowers who alert authorities to alleged instances of scientific misconduct are facing an increasingly hostile environment in which colleagues, research administrators and even investigators called in to examine their claims are closing ranks against them, the annual meeting of the American Association for the Advancement of Science was told last week.

Despite laws that are supposed to protect them, whistleblowers often find themselves subjected to suspicion and investigation, according to Joan Sieber, a psychology professor at California State University. They are statistically likely to lose not only their job, professional friends and status, but even their home and spouse.

According to Robert Sprague, who himself blew the whistle in a celebrated case involving abuses of psychopharmacological research on disabled people, "the scientific community is moving toward suspicion of the whistleblower". It sees them as seeking to benefit, financially or otherwise, from their actions, although this is seldom the case, Sprague says.

Dan Greenberg, editor of the newsletter Science and Government Report, told the meeting that "the scientific establishment doesn't take misconduct seriously, except insofar as it needs to act to placate the political community". Greenberg said that now that Representative John Dingell (Democrat, Michigan), who protected whistleblowers and, as chairman of the House Investigations and Oversight Committee, pursued many well-known cases of alleged misconduct, is in the minority and stripped of his power, scientific leaders "just want to push the whole thing away".

In view of the potential dangers outlined by Sieber, would-be whistleblowers are offered a six-point plan on "how to keep your job" by C. K. Gunsalus, an attorney and administrator at the University of Illinois at Champaign-Urbana. Gunsalus was a member of the Ryan Commission, which last year produced a highly controversial report on scientific misconduct.

Gunsalus suggests that prospective whistleblowers should first show their information to someone they can trust who is in "at least as senior a position" as the subject of the complaint. If possible, they should do this twice, and listen carefully to the responses.

They should then assess what their actual goal is (to have a paper amended, for example), figure out exactly where the relevant documentation will be found, seek allies if possible, and find out the right person to take the allegation to. Only then should they decide whether to proceed.

Gunsalus describes the general response of scientists to misconduct charges as a "visceral" reaction. "We don't like tell-tales, and we don't like our dirty linen to be laundered in public," she says. She also points out that the total number of grievances and lawsuits brought to university administrators by faculty has shot up threefold in recent years. "Something is going on that has made everything [at the universities] much more contentious," she says.

The recommendations of the Ryan Commission are being considered by Donna Shalala, the health secretary, who has referred some of the more contentious ones to the White House. Shalala is expected to revise the process for dealing with misconduct in health research this year, in response to Ryan and to the well-publicized collapse of several high-profile cases at the Office of Research Integrity, which handles such cases in her department.

\section{Marconi's daughter sends out distress call about collection}

\section{[LONDON] The archives of Guglielmo} Marconi (right), the inventor of wireless communication, which had been due for auction in April, are expected to be withdrawn from sale in the wake of a public outcry that included complaints from Marconi's daughter Elettra.

Some 1,000 individual lots, including prototype wireless equipment, documents, photographs and letters, which make up the Marconi Collection, were threatened with dispersal by public auction at Christie's, London, on 24 and 25 April.

But the sale now seems unlikely to go ahead, and a statement from the collection's owners, General Electric Company, which absorbed the Marconi company in 1968, says that discussion is taking place with the Science Museum in London and other parties in a bid to find a solution "which will ensure that the Marconi Collection remains intact and in this country".

Marconi moved to London in 1896 to patent his wireless telegraphy, which had been dismissed in his native Italy, and in the following year registered his Wireless Telegraph and Signal Company. He continued his research in England, and in 1901 successfully received a transatlantic radio signal in St John's, Newfoundland, that had been transmitted in morse code by a colleague in Cornwall, England.
Until this demonstration, radio waves had been received over 80 miles apart, and many scientists believed the waves would be unable to follow a longer curve around the Earth's surface. Marconi shared the Nobel prize for physics in 1909.

Marconi's work provided the foundation of today's terrestrial and satellite broadcasting, sea, air and cellular communications, space travel and radar. Last month, Christie's announced that their auction offered bidders " a unique chance to own a piece of the early days of the global communications industry".

But the news of the intended sale stirred up a flurry of comment in The Times newspaper, including letters from Marconi's daughter, Princess Elettra Marconi-Giovanelli, John Sutherland, the former managing director of Marconi Radar, the historian
Lord Briggs, and archivists and wireless enthusiasts. The main criticism was that the value of the archive derives from its size and breadth, requiring that it be kept intact.

The collection, housed in Great Baddow, near Chelmsford, Essex, is closed to the public, but available for academic study. It includes such items as one of the first commercial wireless receivers, Marconi's diary recording the historic 1901 radio transmission, and a 'Marconigram' sent from the sinking liner Titanic in April 1912.

Christie's said last week that it is waiting for further instructions from General Electric. A spokesman from the company refused to specify the solutions being considered, but said that a final decision on the collection's fate, likely to include withdrawing it from public sale, is expected soon. Claire O'Brien 